
\title{
Reseacch S Suare \\ Effect of Density on Mediterranean Pine Seedlings Using the Nelder Wheel Design: Analysis of Survival and Early Growth
}

Irene Ruano ( $\nabla$ irene@pvs.uva.es )

Universidad de Valladolid https://orcid.org/0000-0003-4059-1928

Valentín Pando

Universidad de Valladolid

Felipe Bravo

Universidad de Valladolid

\section{Research}

Keywords: Establishment, mixed stands, Mediterranean ecosystem, experimental design, Pinus pinaster, Pinus halepensis

Posted Date: September 20th, 2021

DOI: https://doi.org/10.21203/rs.3.rs-903311/v1

License: (a) (1) This work is licensed under a Creative Commons Attribution 4.0 International License. Read Full License 
2

3 Title

4 Effect of density on Mediterranean pine seedlings using the Nelder wheel design: analysis of 5 survival and early growth

6

7 Authors

8 Irene Ruano ${ }^{1,2}$, Valentín Pando ${ }^{1,3}$, Felipe Bravo ${ }^{1,2}$

9

10

Affiliations

11

${ }^{1}$ Instituto Universitario de Investigación Gestión Forestal Sostenible-iuFOR. Universidad de Valladolid-INIA. Avda. Madrid s/n. 34004 Palencia. Spain

${ }^{2}$ Departamento de Producción Vegetal y Recursos Forestales. ETS de Ingenierías Agrarias. Universidad de Valladolid. Palencia. Spain

3 Departamento de Estadística e Investigación Operativa. ETS de Ingenierías Agrarias. Universidad de Valladolid. Palencia. Spain

17

\section{Corresponding author}

Irene Ruano (irene@pvs.uva.es) 


\section{ABSTRACT}

- Background: There is growing interest in mixed-species forests but a lack of studies that analyse them for regeneration phases or any stage other than mature stands. Information is scarce about relatively unproductive species such as Pinus pinaster and Pinus halepensis in Mediterranean ecosystems. The objective of this study was to investigate inter- and intra-specific interactions of both species in different tree densities during the first years of establishment. Five Nelder wheel plots were planted to test densities ranging from 1000 to 80000 seedlings/ha and simulate establishment sub-processes at high densities. Pinus pinaster and Pinus halepensis were mixed along the spokes, to obtain three mixture levels in which $100 \%, 80 \%$ or $60 \%$ of the seedlings were of the same species. Cox proportional-hazards models and binomial logistic regressions were fitted to analyse seedling survival. Early growth (basal diameter and height at one and four years after plantation) was analysed by fitting linear mixed-effects models.

- Results: Pinus halepensis showed higher survival rates and basal diameter increments but more time is needed to know how Pinus pinaster responds to density and mixture.

- Conclusions: Both competitive and facilitating seedling interactions were observed at higher densities, which facilitate seedling survival but decrease early growth. Pinus halepensis showed higher survival rates and basal diameter increments but more time is necessary to determine Pinus pinaster response to density and mixture.

\section{Keywords}

Establishment; mixed stands; Mediterranean ecosystem; experimental design; Pinus pinaster; Pinus halepensis

\section{BACKGROUND}


Germination and establishment are key sub-processes of natural regeneration because seedlings are especially liable to suffer high mortality due to water stress (Grime 1979). This is critical in Mediterranean ecosystems, where high interannual climate variability and strong drought during summer are increasing as a consequence of climate change (IPCC 2007). Environmental conditions for seedlings are especially harsh, so seedling establishment has been studied in terms of scarce natural regeneration (Hanssen 2003; González-Alday et al. 2009; Ruano et al. 2009; Lucas-Borja et al. 2012; Manso et al. 2013...). However, there are also cases of excessive regeneration, for instance in post-fire regeneration of the Pinus genus (Vega et al. 2009; Rodríguez-García et al. 2008; Ruano et al. 2013); so it is interesting to analyse seedling responses to different densities, including high densities.

In mature stands, high densities should cause competition for resources and reduce tree growth, but competitive and facilitating effects are sometimes found simultaneously in other phases of stand development, such as seedling establishment. For example, seedlings might compete for water or light with their own or other species, even as wind velocity or transpiration are reduced by mutual shading or as other species provide protection against herbivores (Jactel and Brockerhoff 2007; Zamora et al. 2008;Uhl et al. 2015). Moreover, positive interactions can become negative as seedlings grow (Callaway et al. 1996; Callaway and Walker 1997; Zamora et al. 2008; Uhl et al. 2015). Some models predict that facilitation and competition interactions vary across abiotic stress gradients and that facilitation interactions will be dominant under stressful conditions, though this is debated (Maestre et al. 2005, 2006; Lortie and Callaway 2006). Therefore, the net effect of intra- and inter-specific interactions among seedlings under high densities is a key issue to analyse.

In the present work, two of the most common pine species in Mediterranean ecosystems were studied: Pinus pinaster Aiton and Pinus halepensis Mill. Both species cover extensive areas in the western Mediterranean basin, while Pinus halepensis populations can be also found in 
eastern Mediterranean zones. From timber, food and energy to soil protection, cultural services, hydrological control, habitat for biodiversity, or climate regulation, forests provide vital ecosystem services (Science for Environment Policy 2015). Pine plantations have been questioned in semi-arid areas in terms of soil fertility, erosion or ecological succession, but they provide more ecosystem services than grasslands, abandoned agricultural fields or other unrestored landscapes (Derak and Cortina 2014). Pinus pinaster and Pinus halepensis have high ecological importance because of their ability to grow in extremely poor soils and survive multiple droughts (Alía and Martín 2003; Fady et al. 2003). The two species share niches, but there are no studies about inter-specific interactions between them. Climate projections for Mediterranean forests predict negative effects at different levels in the future, including reduction of forest and site productivity, increment of disturbances (pests, pathogens, fires...) and shifting species distributions or even extinctions (Resco De Dios et al. 2007, Lindner and Calama 2013). The changes in species distribution and structure that are expected in Mediterranean areas (Thuiller 2003) make it especially timely to study how the selected species will behave together. During seedling development, interactions between coexisting species are key to understanding and predicting specific responses to different densities and mixture ratios.

Inter-specific interactions have been analysed between seedlings and other weed or shrub species (Helliwell and Harrison 1979; Scholes and Archer 1997; De las Heras et al. 2002; Gómez-Aparicio et al. 2005; Rodríguez-García et al. 2011). Despite the increasing interest in mixed-species forests, little research has been done to analyse mixed stands or to compare pure and mixed stands on similar sites, so the discussion is usually theoretical (Pretzsch 2009). Most studies analyse intra- and inter-specific interactions among productive species in mature stands from a productive point of view (Piotto et al. 2004; Kuehne et al. 2013; Vanclay et al. 2013), but there is scarce information about relatively unproductive species and ecosystems or other 
forest stages. The regeneration stage in particular is crucial to stand regeneration and long-term stability.

One of the main issues in this kind of research is the experiment design. The most frequent designs for analysing mixed stands consist of growing two species in varying proportions while keeping stand density constant (Vanclay 2006). Mixed mature stands have been studied in recent years thanks to long-term experimental plots (Pretzsch et al. 2015, 2019a, b; Riofrío et al. 2019; Aguirre et al. 2019...) but little is known about seedling stands or young forests. The Nelder wheel design makes it possible to test multiple densities in a single plot (Nelder 1962; Kerr 2003; Uhl et al. 2015). It consists of a circular plot containing concentric rings radiating outward with spokes that connect the centre with the furthest ring (Figure 1 - experimental design). At the intersections of spokes and arcs, a tree is planted. This creates variable tree densities along the length of the spokes within a single plot.

The main objective of this experimental site was to analyse inter- and intra-specific interactions of Pinus pinaster and Pinus halepensis seedlings in different stand densities. For this, five Nelder wheel plots were planted to test mixed-species densities ranging from 1000 to 80000 seedlings/ha. Results from the analysis of seedling survival and early growth, defined in terms of basal diameter and total height, are presented here. We expected that: (1) seedling survival rates and early growth would be different for Pinus halepensis and Pinus pinaster; (2) seedling survival rates and early growth would be affected by density and mixture levels; (3) the effect of density and mixture levels would be different for each species. The data obtained from this study will contribute to our understanding of inter- and intra-specific interactions during the first years at different stand density levels.

\section{MATERIAL AND METHODS}

\section{Experimental design}


The experimental design consists of four permanent and one temporary Nelder (1962) wheel plots for testing 10 densities. The temporary Nelder wheel plot was installed to harvest the seedlings on two occasions (half each time), for dry biomass analysis. (Ruano et al 2021). All the Nelder wheel plots have 26 spokes, constant angles of $13.85^{\circ}$ and 12 rings, housing a total of 312 seedlings per wheel (Figure 1, experimental design). Trees in the outermost and innermost rings served as buffers for edge effects and were not included in the study sample, leaving 260 seedlings per wheel to analyse. The plots were established during the autumn of 2013 in Calabazanos (Palencia - central Spain), on approximately 1 ha of land located on an old forest nursery site belonging to the Castile-and-Leon Government. The site currently houses the Forest Health Centre (Figure 1). The experimental design was implemented according to the explanations of Parrott et al. (2012).

Ten densities were tested, ranging from 1000 to 80000 seedlings/ha (Table 1). Minimum and maximum densities were also defined, to measure the effects of low and high regeneration densities (Matney and Hodges 1991; Calvo et al 2007; Orozco et al 2007; Ruano et al 2013). Matney and Hodges (1991) identified a recruit density of 2000 seedlings/ha as the minimum requirement for successful natural regeneration. However, a density of 1000-1500 seedlings/ha can be considered satisfactory in stands with abiotic stress (Rodríguez-García et al. 2010), so the minimum density tested was 1000 seedlings/ha. At the other end, high densities have been reported in studies on post-fire natural regeneration in Mediterranean ecosystems (Calvo et al. 2007; Orozco et al. 2007; Ruano et al. 2013). Ruano et al. (2013) observed densities of 80000 seedlings/ha after a fire in Pinus halepensis stands, which served to establish the maximum density at 80000 seedlings/ha in the present study. The same densities were tested for all seedlings of each concentric ring. This will be referred to as the "growing space", which is related to stand density (Table 1). 
Nelder wheel design can also be used to analyse inter-specific interactions. In the present study, Pinus pinaster and Pinus halepensis seedlings were mixed along the spokes (Figure 2). Two regions of provenance - the 'Meseta Castellana' (Castilian High Plains) for Pinus pinaster and 'Repoblaciones de la Meseta Norte' (North Plains Reforestation) for Pinus halepensis - were selected to avoid the site effect. The temporary Nelder wheel plot was installed to harvest the seedlings on two occasions for dry biomass analysis. The design made it possible to look at three mixture levels taking the surrounding seedlings into account: 100 indicates that the central seedling and the four surrounding seedlings are of the same species (100\% of the seedlings are of the same species); 80: the central seedling and three surrounding seedlings are of the same species ( $80 \%$ of the seedlings are of the same species); 60: the central seedling and two surrounding seedlings are of the same species (60\% of the seedlings are of the same species).

One of the aims of the study was to simulate natural regeneration establishment, but the seedlings had to be protected from rabbits given their high population density on the site. We used plastic mesh protectors measuring $60 \mathrm{~cm}$ high, which were as light as possible to avoid changes in micro-climatic conditions. One weed control intervention was also applied during the first summer, to eliminate weed species.

The seedlings were one growing season old when the plantation was established. Basal diameter and total height (length of the main stem) were measured for each plant at that time. The same measurements (basal diameter and total height) were repeated after one year (2014) and after four years (2017) and seedling survival was determined at both times.

\section{Effect of mortality in the experimental design}

When a seedling dies, the growing space of surrounding seedlings changes and thereby alters the initial experimental design. Some authors have done double plantings, but this was not considered in the present study because one of our aims was to analyse seedling survival. 
Another possibility is to remove the seedlings surrounding dead seedlings from the analysis to preserve the initial design (Parrott et al. 2012; Kuehne et al. 2013). In the present work, 984 seedlings survived after a year. If the four seedlings surrounding every dead seedlings had been removed, $52.3 \%$ of the original seedlings would have been eliminated, leaving only 620 seedlings for analysis. We evaluated two options to solve the problem of mortality: i) Hegyi’s competition index, which has been used to estimate local competition in Nelder rings (Weiskittel et al. 2011; Uhl et al. 2015); and ii) recalculating the growing space using Voronoi polygons. Hegyi's index is harder to relate to stand density and the optimal radius must be defined to estimate it correctly (Linares et al. 2009), so Voronoi polygons were calculated in the present study using R Core Team 2020 software with the 'deldir' package (Turner 2020) for 2014 and 2017 (Figure 3). Since the mixture levels defined in the initial design had also changed, mixture levels were recalculated considering surrounding seedlings based on Voronoi polygons. Though four surrounding seedlings were considered in the initial design, the final number of surrounding seedlings depended on the Voronoi polygon. As in the initial design, however, they were estimated as a percentage of surrounding seedlings.

\section{Analysis of seedling survival}

Seedling survival was recorded one year and four years after planting (2014 and 2017) and dead seedlings were found during this period. In 2013, 1300 seedlings (650 of each species) had been planted in the initial design. Approximately $80 \%$ of Pinus pinaster seedlings were alive after a year (2014) and about 40\% were alive after four years (2017). For Pinus halepensis, approximately $89 \%$ of the seedlings were alive after one year and $84 \%$ after four years (2017). Two methods were fitted to analyse which factors affected seedling survival. First, Cox proportional-hazards models (Cox 1972) were fitted to investigate the association between seedling survival time and one or more predictors. The Cox model is expressed by the hazard 
193

function denoted by $h(t)$ and can be interpreted as the risk of dying at time $t$. It can be estimated according to the formula:

$$
h(t)=h_{0}(t) \exp \left(\sum_{i=1}^{n} \beta_{i} X_{i}\right)
$$

Where: $\mathrm{h}(\mathrm{t})$ is the hazard function at time $\mathrm{t} ; \mathrm{h}_{0}(\mathrm{t})$ is the baseline hazard at time $\mathrm{t}$; and $\mathrm{X}_{\mathrm{i}}$ are explanatory variables. This expression gives the hazard rate at time $t$ for object $i$ with covariate vector (explanatory variables) $\mathrm{X}_{\mathrm{i}}$.

In the present study, different Cox proportional-hazards models were fitted to define better predictors. Model significance was confirmed by the Likelihood-Ratio test, Wald test and Score test. Finally, proportional hazards assumptions were tested for the selected Cox regression model.

Basal diameter at time of planting (2013), total height at time of planting (2013), height to diameter ratio (h/d ratio) at time of planting (2013), species (Pinus pinaster, Pinus halepensis), seedling growing space and mixture levels were considered as candidate covariates. Growing space for the seedling and mixture levels were defined in the initial design but had to be recalculated using Voronoi polygons due to mortality. Accordingly, growing space and mixture level were defined as the initial design if the seedling was dead in the 2017 inventory and recalculated using 2014 data and Voronoi polygons if the seedling was alive in 2017.

Second, binomial logistic regressions were fitted to model survival probability. Logistic models are very useful for fitting binary events such as survival or mortality probability, so they have been used in many forestry studies (Yao et al. 2001; Bravo et al. 2001; Trasobares et al. 2004; Bravo-Oviedo et al. 2006; González et al. 2007...). The response variable was a binary variable denoted as "success" (live seedling coded as 1) and "failure" (dead seedling coded as 0). The survival model is as follows: 
$216 P=\frac{1}{1+e^{-\left(\beta_{0}+\sum_{i=1}^{n} \beta_{i} X_{i}\right)}}$

217 Where: $\mathrm{P}$ is the probability of survival; $\beta_{0}$ is the intercept term; and $\mathrm{X}_{\mathrm{i}}$ are the explanatory 218 variables. In this case, the same candidate explanatory variables as those of the Cox 219 proportional-hazards models were considered: basal diameter at time of planting (2013), total height at time of planting (2013), height to diameter ratio (h/d ratio) at time of planting (2013),

221 species (Pinus pinaster and Pinus halepensis), seedling growing space and mixture levels.

222 Cox proportional-hazards models were fitted using the 'survival' package (Therneau 2020). 223 Alternative fits in both analyses were evaluated based on Akaike Information Criterion (AIC) 224 (Akaike 1973) and they were performed using R Core Team 2020 software. The AIC differences $\left(\Delta_{\mathrm{i}}\right)$ were also estimated for all candidate models to determine the empirical support of each model. Thus, $\Delta_{\mathrm{i}}$ is estimated as: $\Delta_{\mathrm{i}}=\mathrm{AIC}_{\mathrm{i}}-\mathrm{AIC} \mathrm{C}_{\min }$ and models with a $\Delta_{\mathrm{i}}>10$ haveessentially no support and might be omitted (Burnham and Anderson 2002). The two selected models were validated graphically.

\section{Analysis of early growth}

Basal diameter and total height were measured at the time of planting, at one year and at four years after plantation (2013, 2014 and 2017). Early growth was analysed considering increments of measured variables over one year (2013-2014) and four years (2013-2017). The data were processed by analysis of variance in a split-plot design model, with the density factor associated to whole plots (rings into the wheels) in a randomized block design with five blocks (the wheel plots), and two factors associated to the split-plots (trees in the rings) in a $2 \times 3$ factorial design (two species and three mixture proportions) with replicates (four trees for 40/60 and 20/80 mixtures, and five trees for no mixture). In this case, when growing space for the 
seedling and mixture levels changed from initial design, they were recalculated again to be considered as the initial design.

The mathematical formulation of the model is given by:

$y_{i j m(k l)}=\mu+\alpha_{i}+\beta_{j}+\gamma_{i j}+\delta_{k}+\eta_{l}+\delta \eta_{k l}+\beta \delta_{j k}+\beta \eta_{j l}+\beta \delta \eta_{j k l}+\varepsilon_{i j m(k l)}$

with $i=1, . ., 5$ for the wheels; $j=1, . ., 10$ for the rings in the wheels; $m=1, . ., 26$ for the trees in the rings, $\mathrm{k}=1,2$ for the species and $\mathrm{l}=1,2,3$ for the mixture levels

where: $\mathrm{y}_{\mathrm{ijm}(\mathrm{kl})}=$ observed increment of basal diameter or height of the tree $\mathrm{m}$ (with species $\mathrm{k}$ and mixture l) in ring j of wheel $\mathrm{i} ; \mu=$ general mean effect; $\alpha_{\mathrm{i}}=$ main effect of the block (wheel) $\mathrm{I} ; \beta_{\mathrm{j}}=$ main effect of density $\mathrm{j} ; \gamma_{\mathrm{ij}}=$ random effect of ring $\mathrm{j}$ in wheel $\mathrm{i}$ (whole-plot error); $\delta_{\mathrm{k}}=$ main effect of species $\mathrm{k} ; \eta_{\mathrm{l}}=$ main effect of the mixture proportion $1 ; \varepsilon_{\mathrm{ijm}(\mathrm{kl})}=$ random error in the observed growth for the tree $\mathrm{m}$ (with species $\mathrm{k}$ and mixture $\mathrm{l}$ ) in ring $\mathrm{j}$ of wheel $\mathrm{i}$.

The other terms are the usual double and triple interactions between factors. The assumptions for the model were:

- $\gamma_{\mathrm{ij}} \sim \mathrm{N}\left(0, \theta^{2}\right)$, with $\theta^{2}=$ random variance for whole plots (rings).

$\bullet \varepsilon_{\mathrm{ijm}(\mathrm{kl})} \leadsto \mathrm{N}\left(0, \sigma_{\mathrm{k}}^{2}\right)$, with $\sigma_{\mathrm{k}}^{2}=$ random variance for errors in the trees of species $\mathrm{k}$.

- $\operatorname{Cov}\left(\gamma_{\mathrm{ij}}, \gamma_{\mathrm{i}^{\prime} \mathrm{j}^{\prime}}\right)=\operatorname{Cov}\left(\varepsilon_{\mathrm{ijm}(\mathrm{kl})}, \varepsilon_{\mathrm{i}^{\prime} \mathrm{j}^{\prime} \mathrm{m}^{\prime}\left(\mathrm{k}^{\prime} \mathrm{l}^{\prime}\right.}\right)=\operatorname{Cov}\left(\gamma_{\mathrm{ij}}, \varepsilon_{\mathrm{i}^{\prime} \mathrm{j}^{\prime} \mathrm{m}^{\prime}\left(\mathrm{k}^{\prime} \mathrm{l}^{\prime}\right.}\right)=0$ for all values of the subscripts.

Therefore, the linear mixed model included three variance parameters, which were estimated using the Restricted Maximum Likelihood Method (REML).

Comparisons between the estimated LS-means were performed using a pairwise t-test with a 0.05 significance level. The normality of the studentized residuals in the model was analysed using the Kolmogorov-Smirnov test. 
Although the statistical design included 1300 trees, only 1101 trees were used at the first date and 799 at the second one, due to mortality. Furthermore, the density and mixture proportion classes of each tree were reassigned based on mortality.

All statistical analyses of early growth were developed using SAS/STAT ${ }^{\circledR}$ software (SAS Institute Inc. 2020). Figures 4 and 5 were developed using R Core Team 2020 software with the 'ggplot2' package (Wickham 2016) from the data obtained in SAS/STAT ${ }^{\circledR}$.

\section{RESULTS}

\section{Analysis of seedling survival}

Seedling survival was analysed using two statistical methods: Cox proportional-hazards regressions and binomial logistic regressions. Same models were fitted for both methods to obtain better conclusions. Based on the AIC differences $\left(\Delta_{\mathrm{i}}\right)$, models 12, 13 and 35 for the Cox proportional-hazards regression and models 13, 21, 28 and 35 for the binomial logistic regression could be considered useful (Supplementary Table 1). In both cases, the Akaike information criterion was lower for models in which the initial size, species, seedling growing space and mixture level were significant (Supplementary Table 1). Model 13, where the basal diameter at time of planting was significant, gave the lowest AIC for the Cox proportionalhazards regression. Model 21, where the basal diameter and the total height at time of planting were significant, gave the lowest AIC for the binomial logistic regression model. However, a similar AIC (1405.14 vs 1405.90; $\left.\Delta_{\mathrm{i}}=0.75\right)$ was obtained with Model 13 and significance levels for tested variables were higher (Supplementary Table 2). Thus, Model 13 was considered the better model for both methods.

A summary of the selected Cox proportional-hazards regression is shown in Table 2. The coefficients in a Cox regression are related to hazard: the negative coefficient of basal diameter indicates a positive effect for seedling survival and the positive coefficients of the other 
significant variables indicate a worse prognosis. The hazard ratios represent instantaneous risk over the study time period for the increment of each explanatory variable by one unit, keeping the other covariates constant. In this case, the expected hazard is 4.86 times higher for Pinus pinaster than Pinus halepensis, when the rest of the variables are fixed. Incrementing the basal diameter by $1 \mathrm{~mm}$ at the time of plantation (one year old) and keeping the other covariates fixed reduces the hazard by a factor of 0.79 . For seedling growing space, hazard increases by a factor of 1.029 when the growing space increases $1 \mathrm{~m}^{2}$ and the other covariates are kept constant. Growing space is related to stand density, so hazard increases with lower densities. Finally, the mixture effect works in a similar way. The hazard increases by a factor of 2.83 when the mixture level increases by 1 unit and other covariates remain constant. In other words, the hazard increases as the species proportion becomes more mono-specific.

For the binomial logistic model, a summary of the selected model is shown in Table 3. According to Equation (2), the fitted survival model is:

$$
P=\frac{1}{1+e^{-(1.700+0.383 * \text { basaldiameter }-2.096 * \text { species }-0.055 * \text { growingspace }-1.365 * \text { mixture })}}
$$

The estimated parameters indicate that seedlings with smaller basal diameter at the time of planting (one year old) have less probability of survival and that the survival probability of Pinus pinaster is lower than that of Pinus halepensis. Also, survival rate decreases as the growing space for a seedling increases. Finally, when species proportion is near mono-specific, the survival probability is lower.

\section{Analysis of early growth}

The mixed linear model of equation (3) was fitted four times to analyse the following response variables: Model 1: increment in basal diameter over one year (2013-2014); Model 2: increment in basal diameter over four years (2013-2017); Model 3: increment in total height over one year 

not possible to consider time as a repeated measurement because the model did not converge.

The blocks (wheels) and the species were significant with a significance level of 0.001 for all models. In Model 1 (one-year basal area increment), the mixture level was significant, with a significance level of 0.05 (Table 5). The one-year increment in basal diameter was higher for Pinus halepensis than for Pinus pinaster. The mixture level was significant and the one-year increment in basal diameter was higher when half of the surrounding seedlings were of the same species as the analysed seedling, and lower when all the surrounding seedlings were of the same species as the analysed seedling (Supplementary Table 2).

In Model 2 (four-year basal area increment), growing space and the interaction between species and growing space were significant, with a significance level of 0.001 . The interaction between the species and the mixture level was also significant, with a level of significance of 0.05 (Table 5). The four-year increment in basal diameter was higher for Pinus halepensis than for Pinus pinaster when growing space remained constant. Higher basal diameter increment values were obtained with $2.32 \mathrm{~m}^{2}$ growing space (approximately 4300 seedlings/ha), though nonsignificant differences appeared with growing spaces above $0.88 \mathrm{~m}^{2}$, indicating that higher basal diameter increments were found in densities of approximately 1000-11400 seedlings/ha. Lower basal diameter increment values were also found with a growing space of $0.13 \mathrm{~m}^{2}$ but were not significantly different compared to a growing space of $0.2 \mathrm{~m}^{2}$ (approximately 49000 80000 seedlings/ha) (Supplementary Table 3).

327 Results for the interaction between species and growing space showed higher basal diameter increments over four years for Pinus halepensis than for Pinus pinaster, but each species had higher and lower values with different growing spaces. Pinus halepensis had a higher basal diameter increment with a growing space of $1.43 \mathrm{~m}^{2}$, but without significant differences 
compared to larger growing spaces (approximately 1000-7000 seedlings/ha) and lower basal diameter increment with smaller growing spaces $\left(0.13 \mathrm{~m}^{2}\right.$, or 80000 seedlings/ha). Like Pinus halepensis, basal diameter increments for Pinus pinaster were also higher with a growing space of $1.43 \mathrm{~m}^{2}$ (approximately 7000 seedlings/ha), but significant differences compared to other growing space levels were less clear. Curiously, lower values were found with a growing space of $6.15 \mathrm{~m}^{2}$ (approximately 1600 seedlings/ha) (Supplementary Table 3 and Figure 4).

Interactions between species and mixture levels for the four-year basal diameter increment again showed higher values for Pinus halepensis than Pinus pinaster. Differences between mixture levels were non-significant for Pinus pinaster. In contrast, Pinus halepensis had higher basal diameter increment when half of the surrounding seedlings were also Pinus halepensis (Supplementary Table 4 and Figure 5).

Finally, species was significant in Models 3 and 4, where the total height increment was analysed over one and four years, respectively. In both cases, total height increment was higher for Pinus halepensis than for Pinus pinaster, but none of the factors were significant enough to subsequently analyse differences in growing spaces or mixture levels (Supplementary Table 5).

\section{DISCUSSION}

Seedling establishment has been studied for different species and places, but mostly in natural forests (Gray and Spies 1997; González-Martínez and Bravo 2001; Hunziker and Brang $2005 \ldots$... In the present study, seedling establishment with high densities was analysed for two species using the Nelder design. This design is more common in agricultural experiments (Hanson et al. 2005; Gaines et al. 2008; Bagavathiannan and Norsworthy 2014...) because crops are annual and mortality problems do not arise. It has not been used much in forestry experiments. 
As with any other method, the Nelder design has different strengths and weaknesses. Most of the traditional designs require much larger areas to analyse different stand densities compared to the Nelder design (Vanclay et al. 2013). Moreover, while monospecific stands can be described at stand level, mixed stands need more complex approaches at tree level. The Nelder design provides an advantage over factorial designs, because the experimental unit is the tree rather than the plot. From a statistical point of view, however, there is high spatial and temporal correlation along with a lack of independence and randomization. This weakness has been a problem for years, but today new statistical methods such as mixed models or generalized additive models can be used (Parrott et al. 2012; Kuehne et al. 2013; Uhl et al. 2015). The main weakness for this study is mortality, but double planting was not feasible because one of our aims was to analyse the effect of density on seedling survival. In this case, the growing space was re-calculated using Voronoi polygons to avoid removing the seedlings surrounding dead seedlings. Therefore, the Nelder design allows for optimal analysis of tree dynamics but requires some conceptual and statistical adaptations (Uhl et al. 2015).

Seedling survival was analysed using two different statistical methods. In both cases, the same model was chosen, and the effect of explanatory variables was similar. Higher survival probabilities were obtained for higher basal diameters in both species. This means that seedling size is important from the beginning. When studying natural regeneration of Pinus sylvestris in Sweden, Ackzell (1993) found that height was significant for survival, based on a mean height difference of $40 \mathrm{~cm}$ between surviving and dead trees.

Both species in this study are defined as well-adapted to summer drought (Alía and Martín 2003; Fady et al. 2003) and high densities have been recorded for both species after fires (Calvo et al. 2007; Ruano et al. 2013). In the present work, however, the survival probability of Pinus halepensis was higher than that of Pinus pinaster. Rodrigo et al. (2004) simulated stochastic models to predict forest dynamics after fire for different Mediterranean species (including Pinus 
pinaster and Pinus halepensis), observing similar behaviour for the two species. Density values of both species were high just after the fire, then decreased considerably during the early postfire years, but had high resilience. This was not the case for mixed stands, however, where the probability of transition to other forest types is high. In the present work, however, seedling survival probability was lower in monospecific stands and points to a facilitating effect between species.

Competition for resources between seedlings may be expected, but our results also indicated a facilitating effect because survival probability was higher with less growing space and higher stand density. Facilitation may occur if wind velocity or transpiration are reduced through mutual shading or if other species provide protection against herbivores (Rodríguez-García et al. 2008; Zamora et al. 2008; Uhl et al. 2015). Bertness and Callaway (1994) considered competition less important than facilitation in low-productivity stands such as the one studied here.

Early growth was analysed based on the increment in basal diameter over one and four years and the increment in total height over one and four years. Differences between species where found in all analyses, with higher values for Pinus halepensis. Pinus pinaster and Pinus halepensis are considered as pioneer and invasive species in terms of ecological succession; they also have similar behaviour in terms of relative growth (Davis et al. 2000; Grotkopp et al. 2002). Grotkopp et al. (2002) analysed relative growth for 29 pine species, including Pinus pinaster and Pinus halepensis. They observed similar relative growth rates between both species, while Pinus halepensis had higher basal diameter increments and total height than Pinus pinaster in the present study. This may be due to a negative relationship between seed weight and relative growth rate. The corresponding theory suggests that species with lighter seeds would have higher relative growth (Marañón and Grubb 1993; Grotkopp et al. 2002). Our analysis supports this theory: Pinus halepensis seeds weigh less than Pinus pinaster seeds 
(Grotkopp et al. 2002) and we observed higher diameter and height increments for Pinus

405

406

407

408

409

410

411

412

413

414

415

416

417

418

419

420

421

422

423

424

425

426

427 halepensis.

Only species was significant in the results for total height increment, which confirms Eichhorn's rule (Eichhorn 1902). It states that the total production of a species at a given height should be identical for all site classes. Thus, production is independent of age and site (Skovsgaard and Vanclay 2008). In this early stage of development, we observed concordance with Eichhorn's empirical rule, which is applied regularly to mature stands.

Another explanation of the difference between the two species in terms of early growth might be found in the specific characteristics of Pinus halepensis. Puértolas et al. (2005) analysed early growth and physiological parameters of Pinus pinea and Pinus halepensis over one year. Apparently, Pinus halepensis could grow higher because it is well-adapted to summer drought. The key moment for this species occurs in May, when water availability is higher. Olivar et al. (2012) also found rainfall during spring to be a key variable for Pinus halepensis growth.

Non-significant influences were found for the other factors and interactions, except in the case of basal diameter. Only mixture level was significant over one year while growing space and interactions between species, mixture levels and growing space were significant over four years. Competition can have an immediate effect on diameter but a delayed effect on height growth (Richardson et al. 1999). Similarly, other factors such as growing space and mixture were nonsignificant over one year but substantial over four years.

The effect of thinning on post-fire natural regeneration has been widely analysed in the Mediterranean basin (Madrigal et al. 2004 for Pinus pinaster; Tsitsoni et al. 2004 for Pinus brutia; Navarro et al. 2010 and Ruano et al. 2013 for Pinus halepensis...). Most studies showed higher diameter increments after a thinning when post-fire natural regeneration was high, indicating that reducing density increases diameter growth. However, the seedling growth 
conditions in those studies were different than those of the present work because apart from mortality, density is constant over the time in Nelder wheel design. In general terms, basal diameter increments over four years were higher where density was lower (between 1000 and 7000 seedlings/ha for Pinus halepensis). In contrast, survival results were higher when seedling density was higher. These results point to simultaneous facilitation and competition effects: survival was higher at higher densities but early growth was lower. So we see that competition and facilitation interactions are complex in the early years.

Regarding stand mixture, Pinus pinaster had similar basal diameter increments over four years regardless of the mixture level. However, basal diameter increments for Pinus halepensis were higher in $60 \%$ mixtures.

We can confirm our first hypothesis that the species studied would have different seedling survival and early growth behaviour. In this case, survival rates and basal diameter increments after four years were higher for Pinus halepensis. We can also confirm the second hypothesis about the effect of density and mixture on survival and early growth: higher densities facilitated seedling survival but basal diameter increments after four years were higher at lower densities. This indicates a complex effect of density: higher densities can be considered a facilitating effect during establishment, when survival is key, but competition interactions emerge during early growth. Species mixture improved both seedling survival rates and basal diameter increments after four years but mixture had no effect on early growth for Pinus pinaster. This confirms our third hypothesis, that the mixture effect would be different for each species.

\section{CONCLUSIONS}

There are competitive and facilitating interactions for seedlings at higher densities. Higher densities facilitate seedling survival but decrease early growth. Pinus halepensis showed higher survival rates and basal diameter increments but more time is necessary to determine Pinus 
pinaster response to density and mixture. Further research is needed on mixed stands, especially

453 during seedling establishment, because little is known about inter- and intra-specific 454 interactions at this key moment for ensuring a successful stand.

\section{DECLARATIONS}

456 Consent to participate: yes

457 Ethics approval: not applicable

458 Consent for publication: not applicable

459 Availability of data and material: The datasets used and/or analysed during the current study 460 are available from the corresponding author on reasonable request.

461 Competing interests: The authors declare that they have no competing interests

\section{Funding:}

463 Spanish Economy and Competitiveness Ministry, "Mixed Forest Complexity and 464 Sustainability: Dynamic, Silviculture and Adaptative Management Tools” Project (AGL2014465 51964-C2-1-R) and European Union, "Mixed Species forest management. Lowering risk, increasing resilience- REFORM” Project (PCIN-2017-027)

\section{Authors' contributions:}

468 Irene RUANO: designed the experiment, conducted field measurements, ran the first version 469 of the data analysis, drafted the manuscript and improved it with comments and suggestions 470 from the other authors.

471 Valentín PANDO: ran the data analysis and collaborated in the first version of the manuscript.

472 Felipe BRAVO: defined the hypothesis, designed the experiment, supervised the work, 473 improved the manuscript with different comments and coordinated the research project. 
475 The authors thank the Castile-and-Leon Forest Services for use of their facilities, their help 476 installing the Calabazanos Nelder wheel experimental site, and their ongoing support.

\section{REFERENCES}

480

481

482

483

484

485

486

487

488

489

490

491

492

493

494

495

Ackzell L (1993) A comparison of planting, sowing and natural regeneration for Pinus sylvestris (L.) in boreal Sweden. For Ecol Manage 61:229-245.

https://doi.org/10.1016/0378-1127(93)90204-Z

Aguirre A, del Río M, Condés S (2019) Productivity Estimations for Monospecific and Mixed Pine Forests along the Iberian Peninsula Aridity Gradient. Forests 10:430. https://doi.org/10.3390/f10050430

Bagavathiannan M V, Norsworthy JK (2014) Pollen-mediated transfer of herbicide resistance in Echinochloa crus-galli. Pest Manag Sci 70:1425-1431. https://doi.org/10.1002/ps.3775

Bertness MD, Callaway R (1994) Positive interactions in communities. Trends Ecol Evol 9:191-193. https://doi.org/10.1016/0169-5347(94)90088-4

Bravo-Oviedo A, Sterba H, del Río M, Bravo F (2006) Competition-induced mortality for Mediterranean Pinus pinaster Ait. and P. sylvestris L. For Ecol Manage 222:88-98. https://doi.org/10.1016/J.FORECO.2005.10.016

Bravo F, Hann DW, Maguire DA (2001) Impact of competitor species composition on predicting diameter growth and survival rates of Douglas-fir trees in southwestern 
497

498

499

500

501

502

503

504

505

506

507

508

509

510

511

512

513

514

515

516

517

Callaway RM, DeLucia EH, Moore D, et al (1996) Competition and facilitation: Contrasting effects of Artemisia tridentata on desert vs montane pines. Ecology 77:2130-2141. https://doi.org/10.2307/2265707

Callaway RM, Walker LR (1997) COMPETITION AND FACILITATION: A SYNTHETIC APPROACH TO INTERACTIONS IN PLANT COMMUNITIES. Ecology 78:19581965. https://doi.org/10.1890/0012-9658(1997)078[1958:CAFASA]2.0.CO;2

Calvo L, Santalla S, Valbuena L, et al (2007) Post-fire natural regeneration of a Pinus pinaster forest in NW Spain. Plant Ecol 197:81-90. https://doi.org/10.1007/s11258-007-9362-1

Davis MA, Grime JP, Thompson K (2000) Fluctuating resources in plant communities: a general theory of invasibility. J Ecol 88:528-534. https://doi.org/10.1046/j.13652745.2000.00473.x

De las Heras J, Martínez-Sánchez JJ, González-Ochoa AI, et al (2002) Establishment of Pinus halepensis Mill. saplings following fire: effects of competition with shrub species. Acta Oecologica 23:91-97. https://doi.org/10.1016/S1146-609X(02)01138-4

Derak M, Cortina J (2014) Multi-criteria participative evaluation of Pinus halepensis plantations in a semiarid area of southeast Spain. Ecol Indic 43:56-68. https://doi.org/10.1016/j.ecolind.2014.02.017

Gaines TA, Brien Henry W, Byrne PF, et al (2008) Jointed Goatgrass (Aegilops Cylindrica) by Imidazolinone-Resistant Wheat Hybridization under Field Conditions. Weed Sci 56:32-36. https://doi.org/10.1614/WS-07-033.1

Gómez-Aparicio L, Valladares F, Zamora R, Luis Quero J (2005) Response of tree seedlings 

to the abiotic heterogeneity generated by nurse shrubs: an experimental approach at different scales. Ecography (Cop) 28:757-768. https://doi.org/10.1111/j.2005.09067590.04337.x

González-Alday J, Martínez-Ruiz C, Bravo F (2009) Evaluating different harvest intensities over understory plant diversity and pine seedlings, in a Pinus pinaster Ait. natural stand of Spain. Plant Ecol 201:211-220. https://doi.org/10.1007/s11258-008-9490-2

González-Martínez SC, Bravo F (2001) Density and population structure of the natural regeneration of Scots pine (Pinus sylvestris L.) in the High Ebro Basin (Northern Spain). Ann For Sci 58:277-288. https://doi.org/10.1051/forest:2001126

González JR, Trasobares A, Palahí M, Pukkala T (2007) Predicting stand damage and tree survival in burned forests in Catalonia (North-East Spain). Ann For Sci 64:733-742. https://doi.org/10.1051/forest:2007053

Gray AN, Spies TA (1997) MICROSITE CONTROLS ON TREE SEEDLING ESTABLISHMENT IN CONIFER FOREST CANOPY GAPS. Ecology 78:2458-2473. https://doi.org/10.1890/0012-9658(1997)078[2458:MCOTSE]2.0.CO;2

Grotkopp E, Rejmánek M, Rost TL (2002) Toward a Causal Explanation of Plant Invasiveness: Seedling Growth and Life-History Strategies of 29 Pine (Pinus) Species. Am Nat 159 (4):396-419

Hanson BD, Mallory-Smith CA, Shafii B, et al (2005) Pollen-Mediated Gene Flow from Blue Aleurone Wheat to Other Wheat Cultivars. Crop Sci 45:1610. https://doi.org/10.2135/cropsci2004.0443

Hanssen KH (2003) Natural regeneration of Picea abies on small clear-cuts in SE Norway. For Ecol Manage 180:199-213. https://doi.org/10.1016/S0378-1127(02)00610-2 
Helliwell DR, Harrison AF (1979) Effects of light and weed competition on the growth of seedlings of four tree species on a range of soils. Forestry 31:37-46

Hunziker U, Brang P (2005) Microsite patterns of conifer seedling establishment and growth in a mixed stand in the southern Alps. For Ecol Manage 210:67-79. https://doi.org/10.1016/J.FORECO.2005.02.019

Jactel H, Brockerhoff EG (2007) Tree diversity reduces herbivory by forest insects. Ecol Lett 10:835-848. https://doi.org/10.1111/j.1461-0248.2007.01073.x

Kerr G (2003) Effects of spacing on the early growth of planted Fraxinus excelsior L. Can J For Res 33:1196-1207. https://doi.org/10.1139/x03-041

Kuehne C, Kublin E, Pyttel P, Bauhus J (2013) Growth and form of Quercus robur and Fraxinus excelsior respond distinctly different to initial growing space: results from 24year-old Nelder experiments. J For Res 24:1-14. https://doi.org/10.1007/s11676-0130320-6

Linares J-C, Delgado-Huertas A, Julio Camarero J, et al (2009) Competition and drought limit the response of water-use efficiency to rising atmospheric carbon dioxide in the Mediterranean fir Abies pinsapo. Oecologia 161:611-24. https://doi.org/10.1007/s00442009-1409-7

Lortie CJ, Callaway RM (2006) Re-analysis of meta-analysis: support for the stress-gradient hypothesis. J Ecol 94:7-16. https://doi.org/10.1111/j.1365-2745.2005.01066.x

Lucas-Borja ME, Fonseca TF, Lousada JL, et al (2012) Natural regeneration of Spanish black pine [Pinus nigra Arn. ssp. salzmannii (Dunal) Franco] at contrasting altitudes in a Mediterranean mountain area. Ecol Res 27:913-921. https://doi.org/10.1007/s11284012-0969-x 
Madrigal J, E MH, Hernando C, et al (2004) Respuesta a Corto Plazo del Regenerado PostIncendio de Pinus pinaster Ait . a Clareos Mecanizados Intensos. Silva Lusit 12:1-14

Maestre FT, Valladares F, Reynolds JF (2005) Is the change of plant-plant interactions with abiotic stress predictable? A meta-analysis of field results in arid environments. J Ecol 93:748-757. https://doi.org/10.1111/j.1365-2745.2005.01017.x

Maestre FT, Valladares F, Reynolds JF (2006) The stress-gradient hypothesis does not fit all relationships between plant-plant interactions and abiotic stress: further insights from arid environments. J Ecol 94:17-22. https://doi.org/10.1111/j.1365-2745.2005.01089.x

Manso R, Fortin M, Calama R, Pardos M (2013) Modelling seed germination in forest tree species through survival analysis. The Pinus pinea L. case study. For Ecol Manage 289:515-524. https://doi.org/10.1016/j.foreco.2012.10.028

Marañón T, Grubb PJ (1993) Physiological Basis and Ecological Significance of the Seed Size and Relative Growth Rate Relationship in Mediterranean Annuals. Funct Ecol 7 (5):591-599

Navarro FB, Jiménez MN, Gallego E, Ripoll M a. (2010) Short-term effects of overstory reduction and slash mulching on ground vegetation in a Mediterranean Aleppo pine woodland. Eur J For Res 129:689-696. https://doi.org/10.1007/s10342-010-0374-3

Olivar J, Bogino S, Spiecker H, Bravo F (2012) Climate impact on growth dynamic and intraannual density fluctuations in Aleppo pine (Pinus halepensis) trees of different crown classes. Dendrochronologia 30:35-47. https://doi.org/10.1016/j.dendro.2011.06.001

Parrott DL, Brinks JS, Lhotka JM (2012) Designing Nelder wheel plots for tree density experiments. New For 43:245-254. https://doi.org/10.1007/s11056-011-9278-4 
Piotto D, Víquez E, Montagnini F, Kanninen M (2004) Pure and mixed forest plantations with native species of the dry tropics of Costa Rica: a comparison of growth and productivity. For Ecol Manage 190:359-372. https://doi.org/10.1016/j.foreco.2003.11.005

Pretzsch H, del Río M, Ammer C, et al (2015) Growth and yield of mixed versus pure stands of Scots pine (Pinus sylvestris L.) and European beech (Fagus sylvatica L.) analysed along a productivity gradient through Europe. Eur J For Res 134:927-947. https://doi.org/10.1007/s10342-015-0900-4

Pretzsch H, del Río M, Biber P, et al (2019a) Maintenance of long-term experiments for unique insights into forest growth dynamics and trends: review and perspectives. Eur. J. For. Res. 138:165-185

Pretzsch H, Steckel M, Heym M, et al (2019b) Stand growth and structure of mixed-species and monospecific stands of Scots pine (Pinus sylvestris L.) and oak (Q. robur L., Quercus petraea (Matt.) Liebl.) analysed along a productivity gradient through Europe. Eur J For Res 1-19. https://doi.org/10.1007/s10342-019-01233-y

Resco De Dios V, Fischer C, Colinas C (2007) Climate change effects on mediterranean forests and preventive measures. New For. 33:29-40

Richardson B, Kimberley MO, Ray JW, Coker GW (1999) Indices of interspecific plant competition for Pinus radiata in the central north island of New Zealand. Can J For Res 29:898-905

Riofrío J, del Río M, Maguire D, Bravo F (2019) Species Mixing Effects on Height-Diameter and Basal Area Increment Models for Scots Pine and Maritime Pine. Forests 10:249. https://doi.org/10.3390/f10030249 
Rodríguez-García E, Bravo F, Spies TA (2011) Effects of overstorey canopy, plant-plant interactions and soil properties on Mediterranean maritime pine seedling dynamics. For Ecol Manage 262:244-251. https://doi.org/10.1016/j.foreco.2011.03.029

614

615

616

617

618

619

620

621

622

623

624

625

626

627

628

629

630

631

Rodríguez-García E, Juez L, Bravo F (2010) Environmental influences on post-harvest natural regeneration of Pinus pinaster Ait. in Mediterranean forest stands submitted to the seed-tree selection method. Eur J For Res 129:1119-1128. https://doi.org/10.1007/s10342-010-0399-7

Rodríguez-García E, Juez L, Guerra B, Bravo F (2008) Análisis de la regeneración natural de Pinus pinaster Ait. en los arenales de Almazán-Bayubas (Soria, España). For Syst 16:2538

Ruano I, Pando V, Bravo F (2009) How do light and water influence Pinus pinaster Ait. germination and early seedling development? For Ecol Manage 258:2647-2653. https://doi.org/10.1016/j.foreco.2009.09.027

Ruano I, Rodríguez-García E, Bravo F (2013) Effects of pre-commercial thinning on growth and reproduction in post-fire regeneration of Pinus halepensis Mill. Ann For Sci 70:357366. https://doi.org/10.1007/s13595-013-0271-2

Scholes RJ, Archer SR (1997) Tree-Grass Interactions in Savannas. Annu Rev Ecol Syst 28:517-544

Sistema de Clasificación Bioclimática Mundial. 1996-2009. S.Rivas-Martínez and S.RivasSáenz. Centro de Investigaciones Fitosociológicas, España. Available from http://www.ucm.es/info/cif [accessed 2 May 2019]. 
Skovsgaard JP, Vanclay JK (2008) Forest site productivity: a review of the evolution of dendrometric concepts for even-aged stands. For An Int J For Res 81:13-31. https://doi.org/10.1093/forestry/cpm041

Thuiller W (2003) BIOMOD - optimizing predictions of species distributions and projecting potential future shifts under global change. Glob Chang Biol 9:1353-1362. https://doi.org/10.1046/j.1365-2486.2003.00666.x

Trasobares A, Pukkala T, Miina J (2004) Growth and yield model for uneven-aged mixtures of Pinus sylvestris L. and Pinus nigra Arn. in Catalonia, north-east Spain. Ann For Sci 61:9-24. https://doi.org/10.1051/forest:2003080

Tsitsoni T, Ganatsas P, Zagas T, Tsakaldimi M (2004) Dynamics of postfire regeneration of Pinus brutia Ten. in an artificial forest ecosystem of northern Greece. Plant Ecol (formerly Veg 171:165-174. https://doi.org/10.1023/B:VEGE.0000029385.60590.fc

Uhl E, Biber P, Ulbricht M, et al (2015) Analysing the effect of stand density and site conditions on structure and growth of oak species using Nelder trials along an environmental gradient: experimental design, evaluation methods, and results. For Ecosyst 2:17. https://doi.org/10.1186/s40663-015-0041-8

Vanclay JK (2006) Experiment designs to evaluate inter- and intra-specific interactions in mixed plantings of forest trees. For Ecol Manage 233:366-374. https://doi.org/10.1016/j.foreco.2006.05.034

Vanclay JK, Lamb D, Erskine PD, Cameron DM (2013) Spatially explicit competition in a mixed planting of Araucaria cunninghamii and Flindersia brayleyana. Ann For Sci 70:611-619. https://doi.org/10.1007/s13595-013-0304-x

Yao X, Titus SJ, MacDonald SE (2001) A generalized logistic model of individual tree 
661

662

663 664 665

mortality for aspen, white spruce, and lodgepole pine in Alberta mixedwood forests. Can J For Res 31:283-291. https://doi.org/10.1139/x00-162

\section{TABLES}

Table 1. Radial length, potential growing space and associated tree density along each spoke of the Nelder wheel plots.

\begin{tabular}{cccc}
\hline Ring & Radial length $(\mathrm{m})$ & Growing space for seedling $\left(\mathrm{m}^{2}\right)$ & Densities tested (seedlings/ha) \\
\hline 0 & 1.14 & - & - \\
1 & 1.45 & 0.13 & 80000 \\
2 & 1.85 & 0.20 & 49162.68 \\
3 & 2.36 & 0.33 & 30212.11 \\
4 & 3.01 & 0.54 & 18566.36 \\
5 & 3.84 & 0.88 & 11409.65 \\
6 & 4.90 & 1.43 & 7011.61 \\
7 & 6.25 & 2.32 & 4308.87 \\
8 & 7.97 & 3.78 & 2647.94 \\
9 & 10.17 & 6.15 & 1627.25 \\
10 & 12.97 & 10.00 & 1000 \\
11 & 16.55 & - & - \\
\hline
\end{tabular}

Table 2. Cox proportional-hazards regression fitted to analyse seedling survival: significant covariates, estimated parameters, standard errors, p-values and hazard ratios with their confidence intervals in brackets, 0.95 probability.

\begin{tabular}{lllll}
\hline Covariates & Parameter & Standard error & $\mathrm{p}$-value & Hazard ratio \\
\hline Basal diameter & -0.233536 & 0.081144 & 0.00400 & $0.791729[0.6753,0.9282]$ \\
Species & 1.581141 & 0.112366 & $<0.001$ & $4.860497[3.8997,6.0580]$ \\
Growing space & 0.028870 & 0.009088 & 0.00149 & $1.029291[1.0111,1.0478]$ \\
Mixture & 1.039063 & 0.194849 & $<0.001$ & $2.826567[1.9293,4.1411]$ \\
\hline
\end{tabular}

Table 3. Binomial logistic regression fitted to analyse seedling survival: explanatory variables, estimated parameters, standard error and p-value. 


\begin{tabular}{llll}
\hline Explanatory variable & Parameter & Standard error & $\mathrm{p}$-value \\
\hline Intercept & 1.70059 & 0.45242 & $>0.001$ \\
Basal diameter & 0.38284 & 0.12210 & 0.0017 \\
Species & -2.09603 & 0.13909 & $<0.001$ \\
Growing space & -0.05497 & 0.01622 & $<0.001$ \\
Mixture & -1.36514 & 0.28757 & $<0.001$ \\
\hline
\end{tabular}

669

670 Table 4. Characteristics of the early growth variables analysed for each species: increment 671 estimates in years (1: one year (2013-2014); 4: four years (2013-2017)) (time); sampling size 672 (n), mean, maximum, minimum and standard deviation.

\begin{tabular}{|c|c|c|c|c|c|c|c|}
\hline Species & Variable & Time & $\mathrm{n}$ & Mean & Max & Min & $\begin{array}{l}\text { Standard } \\
\text { deviation }\end{array}$ \\
\hline \multirow{4}{*}{ 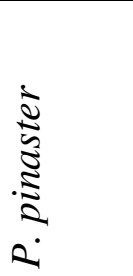 } & Increment of basal diameter $(\mathrm{mm})$ & 1 & 522 & 0.47 & 3.07 & 0.00 & 0.68 \\
\hline & Increment of basal diameter $(\mathrm{mm})$ & 4 & 254 & 5.76 & 35.95 & 0.21 & 4.75 \\
\hline & Increment of total height $(\mathrm{cm})$ & 1 & 522 & 5.91 & 5.91 & 0.00 & 5.59 \\
\hline & Increment of total height $(\mathrm{cm})$ & 4 & 254 & 31.55 & 31.55 & 0.00 & 22.93 \\
\hline \multirow{4}{*}{ 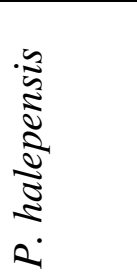 } & Increment of basal diameter $(\mathrm{mm})$ & 1 & 579 & 2.22 & 7.39 & 0.00 & 1.51 \\
\hline & Increment of basal diameter $(\mathrm{mm})$ & 4 & 545 & 25.82 & 68.23 & 2.66 & 12.73 \\
\hline & Increment of total height $(\mathrm{cm})$ & 1 & 579 & 12.40 & 43.50 & 0.00 & 10.03 \\
\hline & Increment of total height $(\mathrm{cm})$ & 4 & 545 & 125.54 & 241.60 & 0.00 & 42.81 \\
\hline
\end{tabular}

673

674 
Table 5. P-values and significant values for early growth factors. Variables: Diameter: basal diameter increment; Height: increment of total height; Time: increment estimates in years (1: one year (2013-2014); 4: four years (2013-2017)). Significance values: ***: p-value <0.001; **: p-value $<0.01 ; *$ : p-value $<0.05 ; \cdot:$ p-value $<0.1 ;$ ns: non-significant effect.

\begin{tabular}{lllllllllll}
\hline Model & Variable & Time & Wheel & Growing space & Species & Mixture & Sp*Mixture & Sp*Space & Space*Mixture & Sp*Space*Mixture \\
\hline 1 & Diameter & 1 & $<0.001 * * *$ & $0.1091 \mathrm{~ns}$ & $<0.001 * * *$ & $0.0314 *$ & $0.7707 \mathrm{~ns}$ & $0.1123 \mathrm{~ns}$ & $0.6635 \mathrm{~ns}$ & $0.4752 \mathrm{~ns}$ \\
2 & Diameter & 4 & $<0.001 * * *$ & $<0.001 * * *$ & $<0.001 * * *$ & 0.0817 & $0.0022 * *$ & $<0.001 * * *$ & $0.0776 \cdot$ & $0.8178 \mathrm{~ns}$ \\
3 & Height & 1 & $<0.001 * * *$ & $0.1753 \mathrm{~ns}$ & $<0.001 * * *$ & 0.0545 & $0.3339 \mathrm{~ns}$ & $0.4854 \mathrm{~ns}$ & $0.8748 \mathrm{~ns}$ & $0.4607 \mathrm{~ns}$ \\
4 & Height & 4 & $<0.001 * * *$ & 0.0988 & $<0.001 * * *$ & $0.118 \mathrm{~ns}$ & $0.377 \mathrm{~ns}$ & $0.4512 \mathrm{~ns}$ & $0.0764 \cdot$ & $0.5415 \mathrm{~ns}$ \\
\hline
\end{tabular}




\section{FIGURES}

Figure 1. Location of the experimental site with a climate diagram (data from Sistema de Clasificación Bioclimática Mundial, 1996-2009). Nelder experimental design (1962): below: dots represent seedlings; distances along spokes and angles between spokes, measured from the centre of the plot.
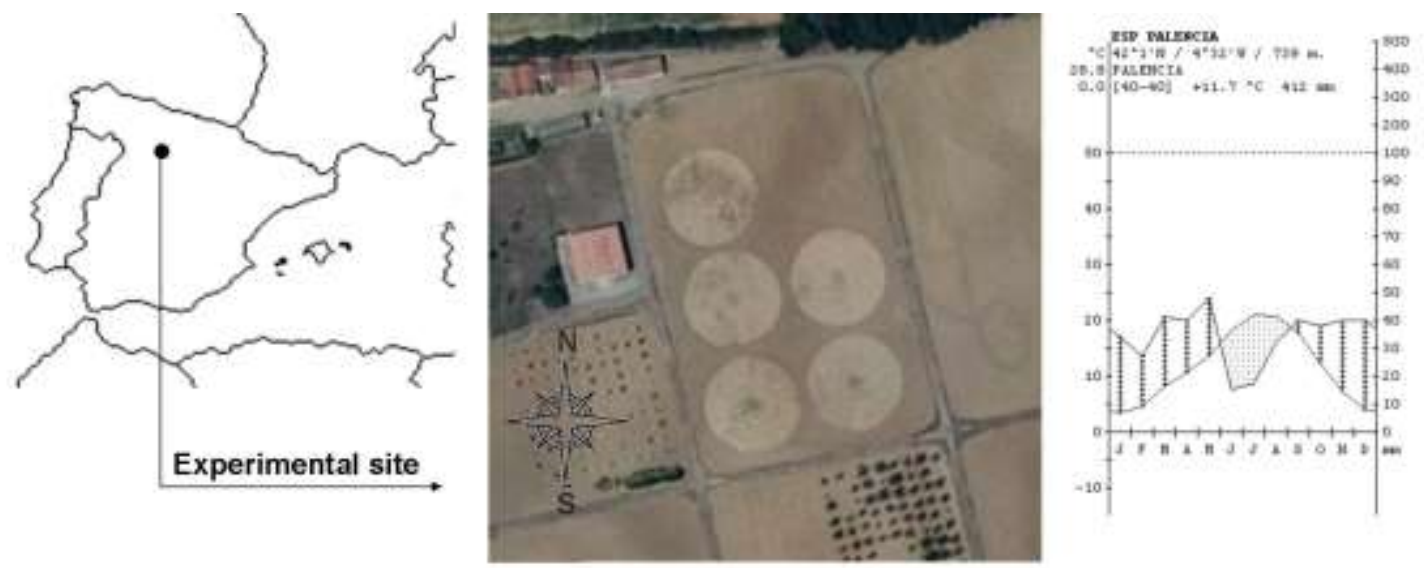

Experimental design:

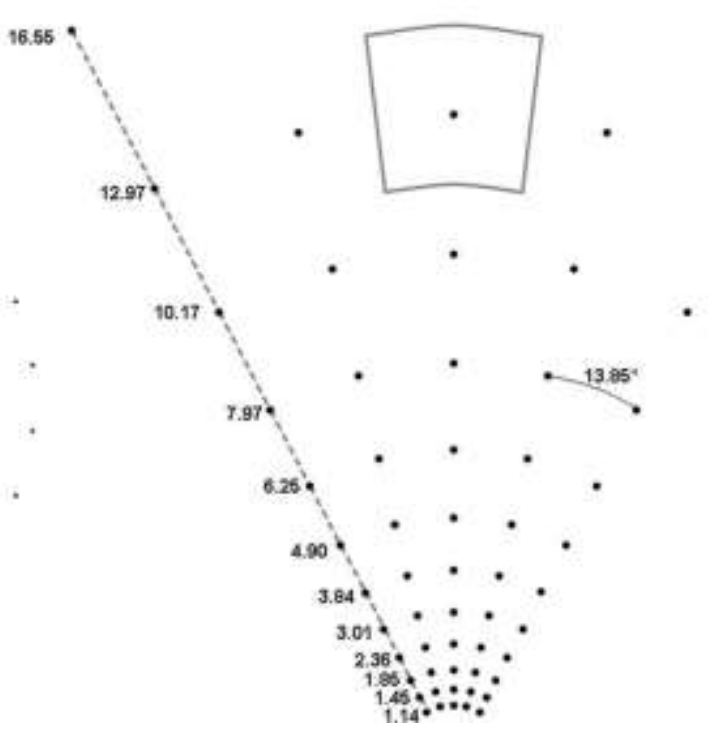

Figure 2. Species distribution along the spokes of the permanent (left plot) and temporal (right plot) Nelder wheels. Mixture levels are shown by percentage examples. Black dots are Pinus pinaster seedlings and white dots are Pinus halepensis seedlings. Grey dots in temporal wheel plot serve as buffers for harvests. 


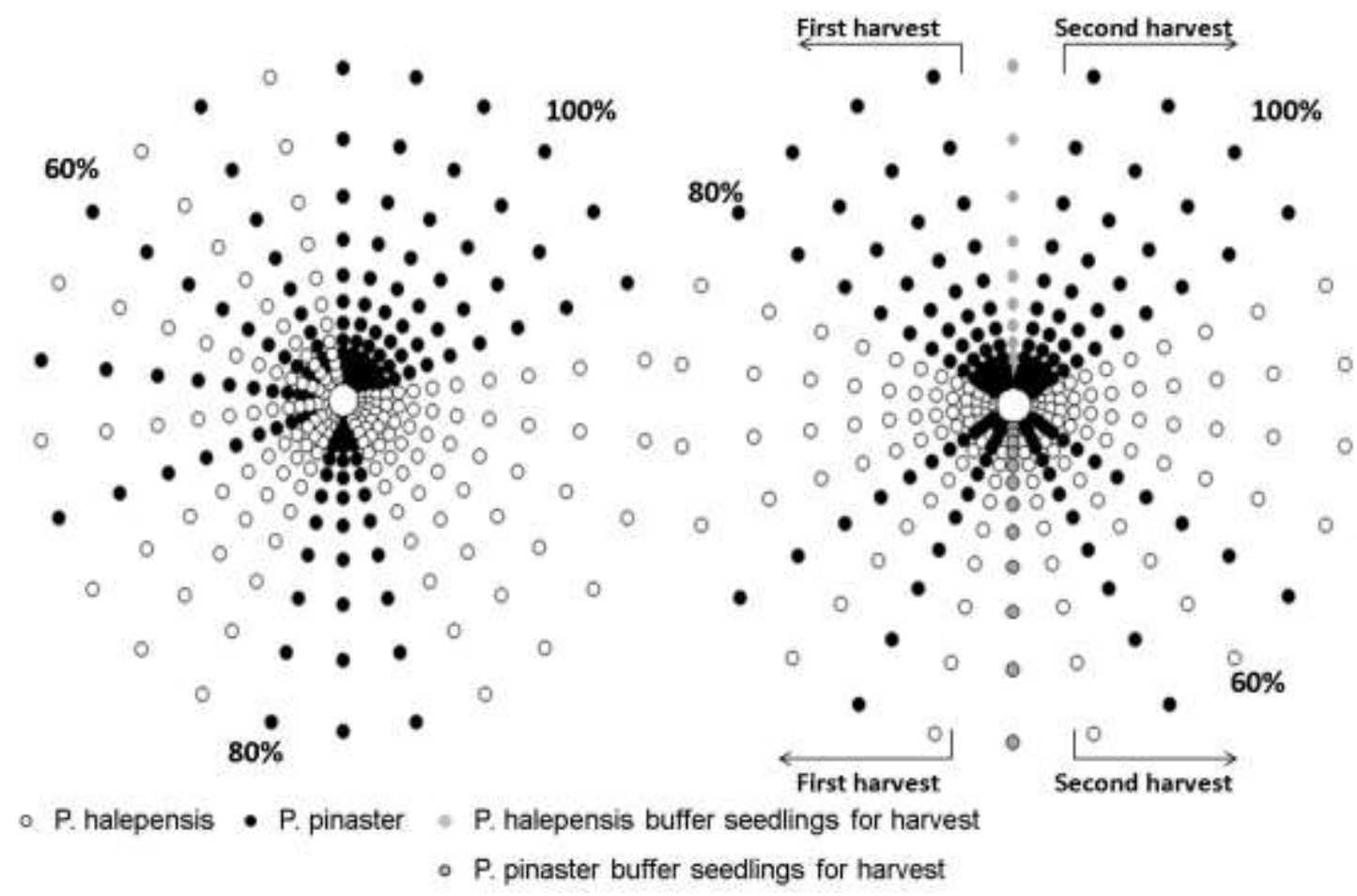

Figure 3. Effect of mortality in the experimental design: initial design, evolution and recalculation of growing spaces using Voronoi polygons. 


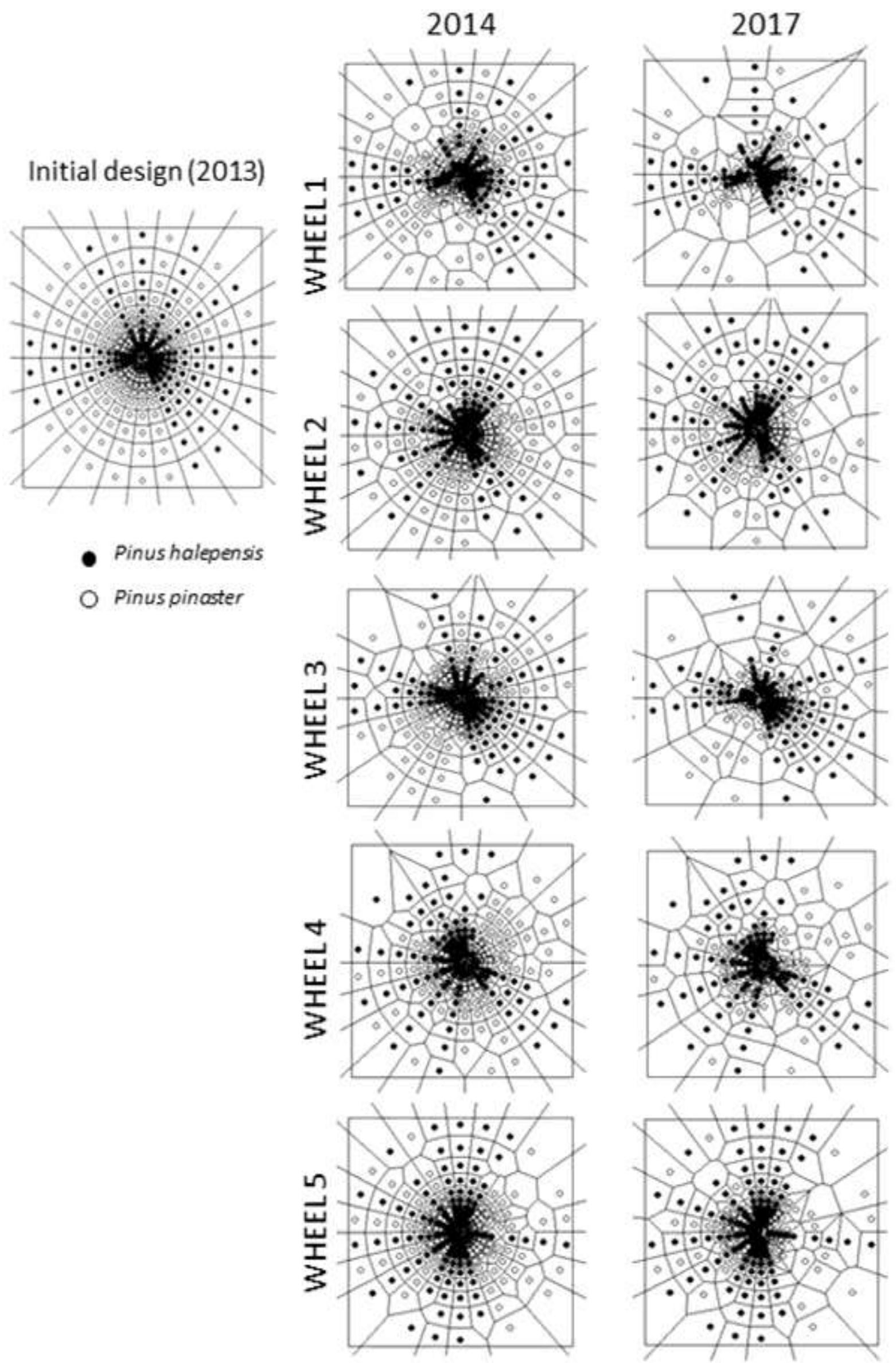


Figure 4. Mean values and confidence intervals for basal diameter over four years, based on the growing space/density of each species and factor level comparison: levels with same letters indicate no significant differences $(\mathrm{P}>0.05)$. Numeric details in Supplementary Table 3.

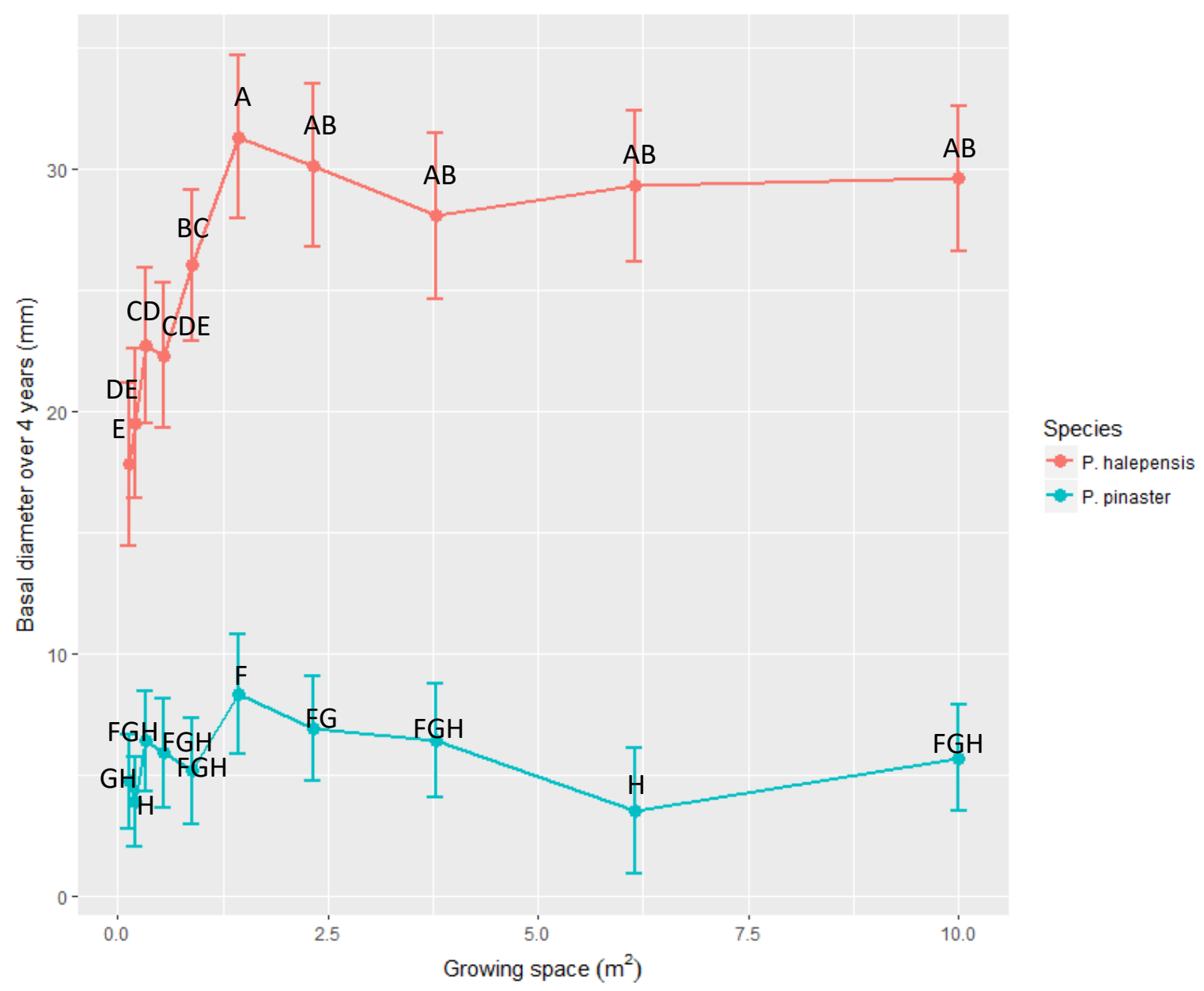

Figure 5. Mean values and confidence intervals for basal diameter over four years based on mixture levels for each species and factor level comparison: levels with same letters indicate no significant differences $(\mathrm{P}>0.05)$. 


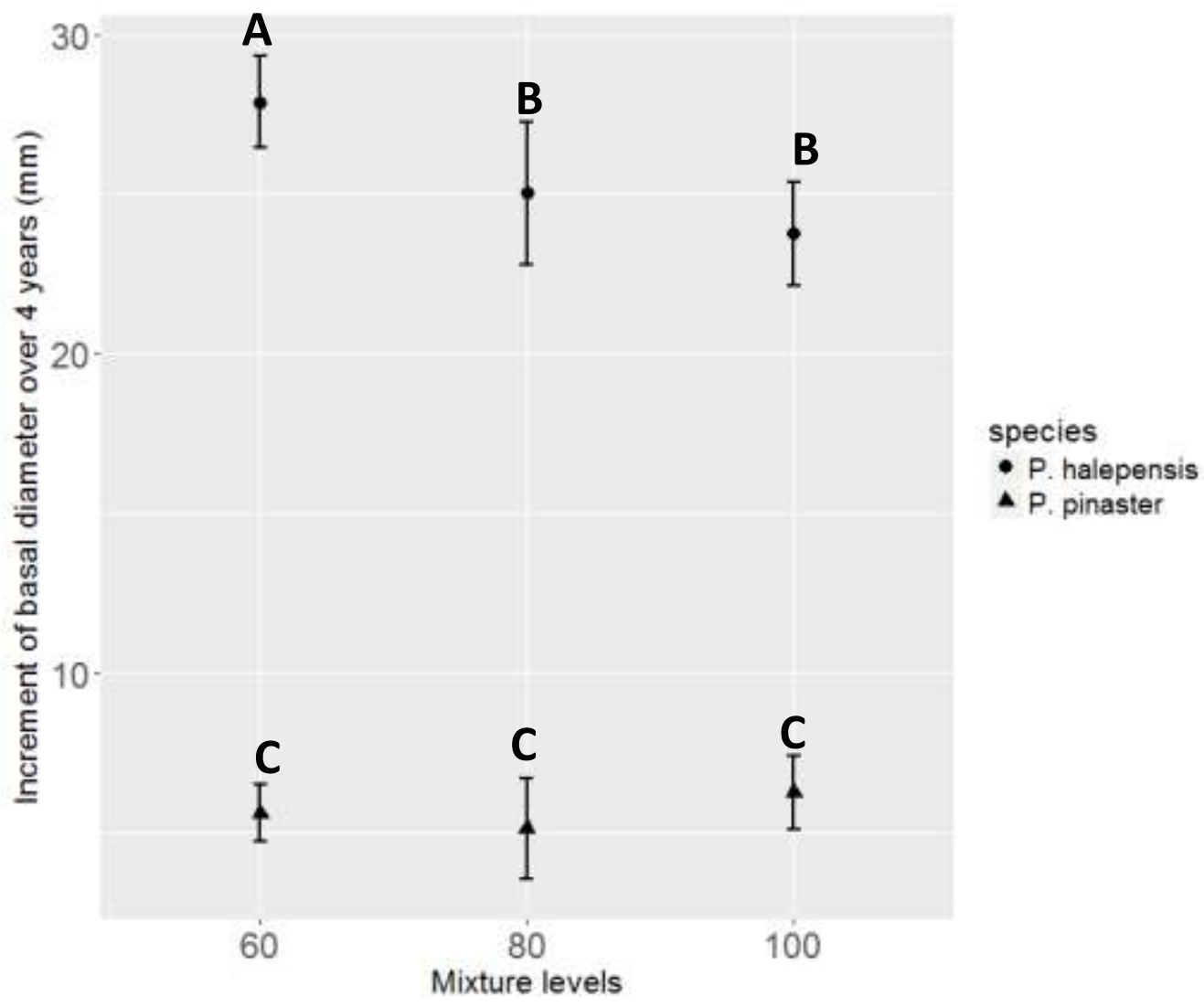




\section{SUPPLEMENTARY MATERIAL}

Supplementary Table 1. Significance of parameters of fitted models for analysing seedling survival: Cox proportional-hazards regressions and binomial logistic regressions. Explanatory variables: d13: basal diameter at time of planting (2013); H13: total height at time of planting (2013); H/d: height to diameter ratio at time of planting (2013); sp: species (Pinus pinaster and Pinus halepensis); gs: growing space for the seedling; mx: mixture level. AIC: Akaike's information criterion. Significance values: ***: p-value <0.001; **: p-value <0.01; *: p-value <0.05; $:$ p-value < 0.1 ; ns: non-significant effect.

\begin{tabular}{|c|c|c|c|c|c|c|c|c|c|c|c|c|c|c|c|c|c|}
\hline \multirow[b]{2}{*}{ model } & \multicolumn{8}{|c|}{ Cox proportional-hazards regressions } & \multicolumn{9}{|c|}{ Binomial logistic regressions } \\
\hline & $\mathrm{d} 13$ & H13 & $\mathrm{H} / \mathrm{d}$ & $\mathrm{sp}$ & gs & $m x$ & AIC & $\Delta_{\mathrm{i}}$ & b0 & $\mathrm{d} 13$ & H13 & $\mathrm{H} / \mathrm{d}$ & $\mathrm{sp}$ & gs & $\mathrm{mx}$ & AIC & $\Delta_{\mathrm{i}}$ \\
\hline 1 & $* * *$ & & & & & & 6911.22 & 269.32 & $* * *$ & $* * *$ & & & & & & 1694.33 & 289.18 \\
\hline 2 & & $* * *$ & & & & & 6849.16 & 207.26 & $* * *$ & & $* * *$ & & & & & 1615.07 & 209.93 \\
\hline 3 & & & $* * *$ & & & & 6872.19 & 230.29 & $* * *$ & & & $* * *$ & & & & 1656.74 & 251.59 \\
\hline 4 & & & & $* * *$ & & & 6699.16 & 57.27 & $* * *$ & & & & $* * *$ & & & 1448.69 & 43.55 \\
\hline 5 & & & & & $* *$ & & 6953.35 & 311.46 & $* * *$ & & & & & $* * *$ & & 1725.92 & 320.78 \\
\hline 6 & & & & & & $* * *$ & 6942.46 & 300.57 & $* * *$ & & & & & & $* * *$ & 1721.48 & 316.33 \\
\hline 7 & $* *$ & & & $* * *$ & & & 6675.82 & 33.93 & $\mathrm{~ns}$ & $* *$ & & & $* * *$ & & & 1436.70 & -1405.14 \\
\hline 8 & $* * *$ & & & & $* *$ & & 6904.14 & 262.24 & $* * *$ & $* * *$ & & & & $* * *$ & & 1685.10 & 279.96 \\
\hline 9 & $* * *$ & & & & & $* * *$ & 6892.30 & 250.41 & $*$ & $* * *$ & & & & & $* * *$ & 1679.89 & 274.75 \\
\hline 10 & $* *$ & & & $* * *$ & $* *$ & & 6669.08 & 27.19 & . & $* *$ & & & $* * *$ & $* * *$ & & 1427.02 & 21.88 \\
\hline 11 & $* * *$ & & & & $* *$ & $* * *$ & 6885.45 & 243.55 & . & $* * *$ & & & & $* * *$ & $* * *$ & 1670.58 & 265.43 \\
\hline 12 & $* *$ & & & $* * *$ & & $* * *$ & 6648.96 & 7.06 & $* * *$ & $* * *$ & & & $* * *$ & & $* * *$ & 1415.79 & 10.65 \\
\hline 13 & $* *$ & & & $* * *$ & $* *$ & $* * *$ & 6641.89 & 0.00 & $* *$ & $* * *$ & & & $* * *$ & $* * *$ & $* * *$ & 1405.90 & 0.75 \\
\hline 14 & ns & $* * *$ & & & & & - & & $* * *$ & ns & $* * *$ & & & & & - & \\
\hline 15 & ns & $\cdot$ & & $* * *$ & & & - & & $\mathrm{ns}$ & $*$ & $\mathrm{~ns}$ & & $* * *$ & & & - & \\
\hline 16 & ns & $* * *$ & & & $* * *$ & & - & & $* * *$ & ns & $* * *$ & & & $* * *$ & & - & \\
\hline 17 & $\mathrm{~ns}$ & $* * *$ & & & & $* * *$ & - & & $* *$ & ns & $* * *$ & & & & $* * *$ & - & \\
\hline 18 & $\mathrm{~ns}$ & $* * *$ & & & & $* * *$ & - & & ns & . & ns & & $* * *$ & $* * *$ & & - & \\
\hline
\end{tabular}




\begin{tabular}{|c|c|c|c|c|c|c|c|c|c|c|c|c|c|c|c|c|c|}
\hline 19 & $\mathrm{~ns}$ & $* * *$ & & & $* *$ & $* * *$ & - & & $*$ & ns & $* * *$ & & & $* * *$ & $* * *$ & - & \\
\hline 20 & ns & . & & $* * *$ & & $* * *$ & - & & $* * *$ & . & ns & & $* * *$ & & $* * *$ & - & \\
\hline 21 & ns & . & & $* * *$ & $* *$ & $* * *$ & - & & $* * *$ & - & - & & $* * *$ & $* * *$ & $* * *$ & 1405.14 & 0.00 \\
\hline 22 & & $* *$ & & $* * *$ & & & 6691.89 & 50.00 & $* *$ & & $* *$ & & $* * *$ & & & 1441.55 & 36.41 \\
\hline 23 & & $* * *$ & & & $* *$ & & 6841.51 & 199.61 & $* * *$ & & $* * *$ & & & $* * *$ & & 1604.42 & 199.28 \\
\hline 24 & & $* * *$ & & & & $* * *$ & 6825.98 & 184.09 & $* *$ & & $* * *$ & & & & $* * *$ & 1598.74 & 193.60 \\
\hline 25 & & $* *$ & & $* * *$ & $* *$ & & 6684.87 & 42.98 & $* * *$ & & $* *$ & & $* * *$ & $* * *$ & & 1431.22 & 26.08 \\
\hline 26 & & $* * *$ & & & $* *$ & $* * *$ & 6818.26 & 176.37 & $*$ & & $* * *$ & & & $* * *$ & $* * *$ & 1587.98 & 182.84 \\
\hline 27 & & $* *$ & & $* * *$ & & $* * *$ & 6665.17 & 23.28 & $* * *$ & & $* *$ & & $* * *$ & & $* * *$ & 1420.79 & 15.64 \\
\hline 28 & & $* *$ & & $* * *$ & $* *$ & $* * *$ & 6657.73 & 15.84 & $* * *$ & & $* *$ & & $* * *$ & $* * *$ & $* * *$ & 1410.21 & 5.06 \\
\hline 29 & & & ns & $* * *$ & & & - & & $* * *$ & & & $\mathrm{~ns}$ & $* * *$ & & & - & \\
\hline 30 & & & $* * *$ & & $* *$ & & 6864.68 & 222.79 & $* * *$ & & & $* * *$ & & $* * *$ & & 1645.80 & 240.66 \\
\hline 31 & & & $* * *$ & & & $* * *$ & 6849.35 & 207.46 & $*$ & & & $* * *$ & & & $* * *$ & 1640.37 & 235.22 \\
\hline 32 & & & . & $* * *$ & $* *$ & & 6675.19 & 33.30 & $* * *$ & & & ns & $* * *$ & $* * *$ & & - & \\
\hline 33 & & & $* * *$ & & $* * *$ & $* * *$ & 6841.52 & 199.62 & ns & & & $* * *$ & & $* * *$ & $* * *$ & - & \\
\hline 34 & & & . & $* * *$ & & $* * *$ & 6654.78 & 12.89 & $* * *$ & & & ns & $* * *$ & & $* * *$ & - & \\
\hline 35 & & & . & $* * *$ & $* *$ & $* * *$ & 6647.29 & 5.40 & $* * *$ & & & . & $* * *$ & $* * *$ & $* * *$ & 1413.13 & 7.98 \\
\hline 36 & & & & $* * *$ & $* *$ & & 6692.15 & 50.26 & $* * *$ & & & & $* * *$ & $* * *$ & & 1438.66 & 33.51 \\
\hline 37 & & & & & $* *$ & $* * *$ & 6934.92 & 293.02 & $* * *$ & & & & $* * *$ & & $* * *$ & 1428.04 & 22.90 \\
\hline 38 & & & & $* * *$ & & $* * *$ & 6672.28 & 30.38 & $* * *$ & & & & $* * *$ & $* * *$ & $* * *$ & 1417.74 & 12.59 \\
\hline 39 & & & & $* * *$ & $* *$ & $* * *$ & 6664.83 & 22.94 & $* * *$ & & & & & $* * *$ & $* * *$ & 1711.96 & 306.82 \\
\hline
\end{tabular}


Supplementary Table 2. Model 1: significant factors affecting basal diameter increment over one year and comparison of means. Values: LS means, standard error and confidence intervals. Comparison: factor levels with same letters indicate no significant differences $(\mathrm{P}>0.05)$.

\begin{tabular}{llll}
\hline Significant factor & Factor levels & Values & Comparison \\
\hline Species & P. halepensis & $\begin{array}{l}2.2047(0.06049) \\
{[2.0860,2.3234]}\end{array}$ & $\mathrm{a}$ \\
& & $0.4518(0.03305)$ & $\mathrm{b}$ \\
& P. pinaster & {$[0.3869,0.5167]$} & \\
\hline Mixture & 0.6 & $1.4380(0.05074)$ & $\mathrm{A}$ \\
& & {$[1.3384,1.5376]$} & \\
& 0.8 & $1.2695(0.07473)$ & $\mathrm{AB}$ \\
& & {$[1.1229,1.4162]$} & \\
& 1 & $1.2315(0.05847)$ & $\mathrm{B}$ \\
& & {$[1.1167,1.3462]$} & \\
\hline
\end{tabular}

Supplementary Table 3. Model 2: Significant factors affecting basal diameter increment over four years and comparison of means (I): species, growing space $\left(\mathrm{m}^{2}\right)$ and interaction between them. Values: LS means, standard error and confidence intervals. Comparison: factor levels with same letters indicate no significant differences $(\mathrm{P}>0.05)$.

\begin{tabular}{|c|c|c|c|c|c|c|}
\hline & Species & & & & & \\
\hline $\begin{array}{l}\text { Growing } \\
\text { space }\end{array}$ & Pinus halepensis & & Pinus pinaster & & $\begin{array}{l}\text { With constant } \\
\text { species }\end{array}$ & \\
\hline 0.13 & $\begin{array}{l}17.8261(1.7147) \\
{[14.4595,21.1927]}\end{array}$ & $E$ & $\begin{array}{l}4.7491(1.0009) \\
{[2.7839,6.7143]}\end{array}$ & $G H$ & $\begin{array}{l}11.3465(1.0767) \\
{[9.1628,13.53029]}\end{array}$ & $\mathrm{E}$ \\
\hline 0.2 & $\begin{array}{l}19.4885(1.5698) \\
{[16.4063,22.5706]}\end{array}$ & $D E$ & $\begin{array}{l}3.8915(0.9455) \\
{[2.0351,5.7478]}\end{array}$ & $H$ & $\begin{array}{l}11.7504(1.0051) \\
{[9.7121,13.7888]}\end{array}$ & $\mathrm{DE}$ \\
\hline 0.33 & $\begin{array}{l}22.7209(1.6238) \\
{[19.5328,25.9089]}\end{array}$ & $C D$ & $\begin{array}{l}6.423(1.0543) \\
{[4.3530,8.4930]}\end{array}$ & $F G H$ & $\begin{array}{l}14.7033(1.0560) \\
{[12.5616,16.8451]}\end{array}$ & $\mathrm{BCD}$ \\
\hline 0.54 & $\begin{array}{l}22.3139(1.5240) \\
{[19.3217,25.3061]}\end{array}$ & $C D E$ & $\begin{array}{l}5.9166(1.1373) \\
{[3.6837,8.1496]}\end{array}$ & $F G H$ & $\begin{array}{l}14.4189(1.0453) \\
{[12.2989,16.5390]}\end{array}$ & $\mathrm{CD}$ \\
\hline
\end{tabular}




\begin{tabular}{|c|c|c|c|c|c|c|}
\hline 0.88 & $\begin{array}{l}26.0136(1.5798) \\
{[22.9119,29.1153]}\end{array}$ & $B C$ & $\begin{array}{l}5.1811(1.1162) \\
{[2.9896,7.3727]}\end{array}$ & $F G H$ & $\mid \begin{array}{l}16.0208(1.0610) \\
{[13.8691,18.1725]}\end{array}$ & $\mathrm{ABC}$ \\
\hline 1.43 & $\begin{array}{l}31.3030(1.7118) \\
{[27.9421,34.6640]}\end{array}$ & $A$ & $\begin{array}{l}8.3631(1.2491) \\
{[5.9106,10.8156]}\end{array}$ & $F$ & $\begin{array}{l}18.2732(1.1002) \\
{[16.0418,20.5045]}\end{array}$ & A \\
\hline 2.32 & $\begin{array}{l}30.1340(1.7020) \\
{[26.7924,33.4756]}\end{array}$ & $A B$ & $\begin{array}{l}6.9137(1.1010) \\
{[4.7521,9.0753]}\end{array}$ & $F G$ & $\begin{array}{l}18.7981(1.1027) \\
{[16.5617,21.0344]}\end{array}$ & A \\
\hline 3.78 & $\begin{array}{l}28.0618(1.7368) \\
{[24.6518,31.4718]}\end{array}$ & $A B$ & $\begin{array}{l}6.4328(1.1862) \\
{[4.1040,8.7617]}\end{array}$ & $F G H$ & $\begin{array}{l}17.5344(1.1360) \\
{[15.2306,19.8383]}\end{array}$ & $\mathrm{AB}$ \\
\hline 6.15 & $\begin{array}{l}29.2815(1.5928) \\
{[26.1542,32.4088]}\end{array}$ & $A B$ & $\begin{array}{l}3.5257(1.3229) \\
{[0.9284,6.1230]}\end{array}$ & $H$ & $\begin{array}{l}16.4936(1.1148) \\
{[14.2328,18.7545]}\end{array}$ & $\mathrm{ABC}$ \\
\hline 10 & $\begin{array}{l}29.6052(1.5263) \\
{[26.6086,32.6018]}\end{array}$ & $A B$ & $\begin{array}{l}5.7301(1.1054) \\
{[3.5598,7.9004]}\end{array}$ & $F G H$ & $\begin{array}{l}17.3867(1.0209) \\
{[15.3163,19.4572]}\end{array}$ & $\mathrm{AB}$ \\
\hline $\begin{array}{l}\text { With } \\
\text { constant } \\
\text { growing } \\
\text { space }\end{array}$ & $\begin{array}{l}25.7930(0.5147) \\
{[24.7824,26.8035]}\end{array}$ & $\mathrm{a}$ & $\begin{array}{l}5.7191(0.3712) \\
{[4.9903,6.4479]}\end{array}$ & $\mathrm{b}$ & & \\
\hline
\end{tabular}

Supplementary Table 4. Model 2: Significant factors affecting basal diameter increment over four years and comparison of means (II): interaction between species and mixture levels. Values: LS means, standard error and confidence intervals. Comparison: factor levels with same letters indicate no significant differences $(\mathrm{P}>0.05)$.

\begin{tabular}{|c|c|c|}
\hline & Species & \\
\hline Mixture & P. halepensis & P. pinaster \\
\hline 60 & $\begin{array}{l}27.8840(0.7299) \\
{[26.4510,29.3171] \mathrm{A}}\end{array}$ & $\begin{array}{l}5.6138(0.4450) \\
{[4.7401,6.4874]}\end{array}$ \\
\hline 80 & $\begin{array}{l}25.0300(1.1401) \\
{[22.7915,27.2685]}\end{array}$ & $\begin{array}{l}5.1147(0.7999) \\
{[3.5442,6.6851]}\end{array}$ \\
\hline 100 & $\begin{array}{l}23.7532(0.8230) \\
{[22.1374,25.3690]}\end{array}$ & $\begin{array}{l}6.2593(0.5899) \\
{[5.1010,7.4176]}\end{array}$ \\
\hline
\end{tabular}

Supplementary Table 5. Models 3 and 4: Significant factors affecting total height increment over one and four years and comparison of means (II): species. Values: LS means, standard error and confidence intervals. Comparison: factor levels with same letters indicate no significant differences $(\mathrm{P}>0.05)$. 


\begin{tabular}{lllll}
\cline { 2 - 4 } & Species & & \\
\hline model & Pinus halepensis & Pinus pinaster & \\
\hline 3 & $12.3377(0.4434)$ & A.7906 (0.2875) & B \\
& {$[11.4676,13.2078]$} & & {$[5.2263,6.3548]$} & B \\
4 & $124.30(1.8077)$ & a & $30.5963(1.7874)$ & \\
& {$[120.75,127.85]$} & & {$[27.0870,34.1057]$} & \\
\hline
\end{tabular}

